\title{
Phenol adsorption onto coffee waste - granular activated carbon: kinetics and equilibrium studies in aqueous solutions
}

\author{
María de la Luz Díaz de León-Garza, Eduardo Soto-Regalado*, \\ Margarita Loredo-Cancino, Felipe de Jesús Cerino-Cordova, \\ Refugio Bernardo García-Reyes, Nancy Elizabeth Dávila-Guzmán, \\ José Ângel Loredo-Medrano
}

Facultad de Ciencias Químicas, Universidad Autónoma de Nuevo León, Av. Universidad S/N, Cd. Universitaria, San Nicolás de los Garza, NL 66455, México, Tel/Fax: + 52 8183294000; emails: eduardo.sotorg@uanl.edu.mx (E. Soto-Regalado), ml.diaz@hotmail.com (M.d.l.L.Díaz de León-Garza),margarita.loredocn@uanl.edu.mx (M. Loredo-Cancino), felipejccuanl@yahoo.com.mx (F.d.J.Cerino-Córdova),bernardogarciareyes@yahoo.com.mx (R.B. García-Reyes), nancy.davilagz@uanl.edu.mx (N.E. Dávila-Guzmán), jaloredom@hotmail.com (J.Á. Loredo-Medrano)

Received 14 February 2017; Accepted 4 September 2017

\section{A B S T R A C T}

In this research, the production of granular activated carbon from coffee waste (CW) by chemical activation with zinc chloride was studied by using a $2^{3}$ factorial design with the three responses (surface area, yield, and hardness) and studying three factors (the activation temperature, activation time, and impregnation ratio). The findings expose that after the experimental design, the highest response values were achieved at an activation temperature of $600^{\circ} \mathrm{C}$, an activation time of $40 \mathrm{~min}$, and an impregnation ratio of $1.5 \mathrm{~g} \mathrm{ZnCl}_{2} \mathrm{~g}^{-1} \mathrm{CW}$. At these conditions, the experimental tests produced a surface area of $1,279 \mathrm{~m}^{2} \mathrm{~g}^{-1}$. Batch studies of phenol adsorption onto coffee waste-activated carbon (CW-GAC) were performed at different solution $\mathrm{pH}$, stirring speeds, and initial phenol concentrations. The maximum phenol adsorption capacity onto CW-GAC was $160.52 \mathrm{mg} \mathrm{g}^{-1}$ at $\mathrm{pH}$. The adsorption kinetics was affected by stirring speed, the required time to achieve equilibrium decreased from 150 to $120 \mathrm{~min}$ when stirring speed varied from 200 to $400 \mathrm{~min}^{-1}$. Film and intraparticle diffusion mechanisms controlled the adsorption of phenol onto CW-GAC. Finally, the porous material developed in this research is capable of sequestering phenol from aqueous solutions to a higher extent than similar lignocellulosic-based activated carbons.

Keywords: Adsorption; Coffee; Factorial experimental design; Granular activated carbon; Lignocellulosic waste

\footnotetext{
* Corresponding author.
} 